\title{
Promoting Health and Safety in Construction through the Procurement Process
}

\author{
Elijah Frimpong Boadu *, Riza Yosia Sunindijo (D) and Cynthia Changxin Wang (D) \\ School of Built Environment, The University of New South Wales, Sydney, NSW 2052, Australia; \\ r.sunindijo@unsw.edu.au (R.Y.S.); cynthia.wang@unsw.edu.au (C.C.W.) \\ * Correspondence: b.frimpong@unsw.edu.au
}

check for updates

Citation: Boadu, E.F.; Sunindijo, R.Y.; Wang, C.C. Promoting Health and Safety in Construction through the Procurement Process. Buildings 2021, 11, 437. https://doi.org/10.3390/ buildings11100437

Academic Editor:

Derek Clements-Croome

Received: 25 August 2021

Accepted: 24 September 2021

Published: 27 September 2021

Publisher's Note: MDPI stays neutra with regard to jurisdictional claims in published maps and institutional affiliations.

Copyright: (C) 2021 by the authors Licensee MDPI, Basel, Switzerland. This article is an open access article distributed under the terms and conditions of the Creative Commons Attribution (CC BY) license (https:// creativecommons.org/licenses/by/ $4.0 /)$.

\begin{abstract}
This study explored the impact of considering health and safety (H\&S) in the construction procurement process based on the extent of $H \& S$ implementation on projects. Underpinned by information integration and rational decision-making theories, the study evaluated how the integration of $H \& S$ objectives into the overall project objectives, and the subsequent consideration of H\&S matters in procurement decisions, influence H\&S implementation on projects. Data were collected using questionnaire surveys from 287 respondents in Ghana who had direct involvement in the project procurement process. The survey explored the extent of H\&S integration into the procurement process and its subsequent impact on H\&S implementation. Path analysis was carried out to determine the causal relationships between the various procurement processes and H\&S implementation. The results demonstrate that setting H\&S objectives and integrating H\&S into the planning stage decisions have a significant impact on the extent to which H\&S matters are considered in the tendering and tender evaluation stages, as well as the H\&S provisions in conditions of contracts. It also showed that adequate $\mathrm{H} \& S$ consideration in these procurement stages subsequently influences $H \& S$ consideration in contract administration and monitoring and ultimately influences the extent of H\&S implementation. These findings demonstrate the importance of integrating H\&S in all aspects of construction procurement to promote H\&S implementation on projects.
\end{abstract}

Keywords: health and safety; procurement process; information integration theory; rational decisionmaking theory; implementation

\section{Introduction}

Many arrangements have been made to address construction health and safety (H\&S) problems worldwide. These include, but are not limited to, passage of legislation, establishment of health and safety enforcement institutions, H\&S management systems, and development of H\&S policies. These arrangements are highly centred on contractors to manage construction health and safety; yet contractors perceive health and safety compliance as an additional economic burden, which reduces their profit margins [1].

Studies have revealed that many on-site accidents can be attributed to managerial decisions made well before the commencement of work on the construction site $[2,3]$. Accordingly, Lingard et al. [2] recommended that the responsibilities for the management of H\&S be driven up the supply chain and involve construction clients and designers. A plethora of studies have revealed the important role of client leadership as a crucial driver for improving H\&S performance in construction projects [4-6]. Clients have substantial influence and contractual control, and their decisions and approaches determine who makes up the project team, their competences, when they are appointed, and the duties assigned to them [7]. Thus, clients are best positioned to demand H\&S processes and outcomes [8].

Over the past few decades, there have been increased calls for clients to integrate $H \& S$ matters into their procurement processes, which govern how projects are executed, including contractual relationships, and risk allocation [9]. Nonetheless, promoting H\&S 
through construction procurement has not received much attention, particularly from the developing countries perspective [10]. Several guidance documents have been developed to promote $H \& S$ in construction procurement [11-13], and studies such as those by Boadu et al. [14], the Health and Safety Executive (HSE) [15], and HSE [16] have assessed the extent of $\mathrm{H} \& \mathrm{~S}$ integration into the construction procurement process. Other studies have explored $H \& S$ issues in construction procurement and made recommendations for improvement $[9,17]$. However, to date little has been done in considering a model to evaluate the effect of $H \& S$ integration into the procurement process on the extent of H\&S implementation on projects. It is in this regard that this study seeks to develop such a model to demonstrate the importance of prioritising and giving $\mathrm{H} \& \mathrm{~S}$ adequate consideration in the construction procurement process.

Promoting H\&S via procurement has been discussed often in the context of developed countries, but empirical investigation in developing countries where construction is growing rapidly is rare [10]. To fill in the gap, this study considered Ghana as a case study of developing countries. Ghana was chosen because it has received significant attention in the H\&S literature [14] as a country whose industrial, economic, and social characteristics are similar to those of many other developing countries.

\section{Theoretical Background and Hypotheses}

Construction procurement activities involve identification of requirements, market sourcing, selection of tenders, evaluation of tenders, contract award, and managing and evaluation of delivery [18]. These processes are underpinned by methods and procedures, which are informed and shaped by the client's objectives, as well as societal goals $[19,20]$. It has been acknowledged that the selection of appropriate procurement strategy is a key determinant of project success. Likewise, choosing an inappropriate procurement approach has been recognised as a primary cause of project failure [21].

The literature on procurement can be drawn from diverse theoretical backgrounds and a wide range of disciplines [22]. Reflecting on the construction procurement processes, clients firstly establish a set of project objectives, which in effect establishes overarching performance requirements for the project [20,23]. Setting the project objectives requires the client to consider both the primary and secondary goals that are needed to be achieved within the project. Thus, clients make project decisions with respect to multiple and potentially competing objectives, and often amid uncertainty. Mostly, these procurement decisions need to be made in a set order and re-evaluated before the next decision as an earlier choice could potentially impact on how situations evolve.

Typically, for an objective (such as H\&S) to be considered and manifested in the procurement decisions, it needs to be prioritised and carefully integrated with other objectives to achieve the desired outcome [24]. Accordingly, this research applies the theoretical concepts of information integration theory (IIT) and rational decision-making to explore the principles, attitudes, and assumptions for prioritising and integrating different sets of project objectives, and the subsequent decision-making in the procurement process, in order to promote H\&S.

\subsection{Information Integration Theory (IIT)}

The information integration theory (IIT) developed and refined by Norman Anderson since the late 1950s explores how attitudes are formed and changed through the integration of new information with existing thoughts. The theory posits that in decision-making, one is affected by each relevant piece of information in its intended way [25]. Each piece of relevant information also has two important characteristics that are vital to decisionmaking: value and weight. Both factors influence attitudes. The value of information is whether that information is favourable or unfavourable, and the weight of a piece of information is the information's perceived importance. Therefore, a piece of information that is high in value (highly favourable or highly unfavourable), and high in weight (very 
important) will have more influence on attitudes than the information which is low in value or weight.

Typically, construction clients are under pressure to deliver projects on time, budget, and of an agreed quality. Besides, an accident-free work environment is increasingly seen as necessary in achieving these goals [26]. As such, H\&S information must be treated as important and valuable in order to be integrated into the overall objectives. For instance, in many countries such as the UK and Australia, H\&S legislation places obligations on both the client and the contractor to minimise the risk of work-related illness and injuries. Furthermore, integrating H\&S in procurement decisions can lead to cost reduction, improved productivity, better prediction and management of production and operational costs, as well as innovation in design and construction [27]. This means that H\&S matters are important information that construction clients cannot ignore and should be an integral part of their projects.

IIT provides options for creating or encouraging attitude change. An individual's attitude is primarily shaped by the information that is valuable (favourable or unfavourable) and important. Thus, the higher the value and weight of a piece of information, the more influence that the information has on one's attitudes [28]. This means that when clients are presented with H\&S information, especially on their legal obligations under H\&S laws and how H\&S influences other project outcomes, these clients will value the information and consequently integrate H\&S into the overall project objective, thereby developing an appropriate procurement strategy.

\subsection{Decision-Making Paradigm}

The development of an appropriate procurement strategy is an important decision if a project is to be successfully executed [29]. From the onset of projects, most clients will want to ensure that their projects will be completed within the set objectives. Deciding and developing an appropriate procurement strategy will potentially ensure satisfactory outcomes and hence minimise the risk of disappointment. The use of decision-making paradigms, such as rational decision-making theory, can assist the client to make better decisions.

Decision theory presents an analytic and systematic approach to decision-making. It encompasses streams of approaches, interpretations, and ideas, and it investigates how individuals, groups or organisations solve or should solve problems [30]. Decision theory posits that a good decision 'is one that is based on logic, considers all available data and possible alternatives, and uses quantitative methods and decision models' [31].

Decision-making models have been used to theorise many procurement strategic decisions in the construction industry $[32,33]$. The rational decision-making model is adopted for this study because it helps decision-makers to structure and organise their decision-making process based on set objectives [34]. According to this approach, decision makers enter decision conditions with clearly known objectives and these objectives determine the possible course(s) of action and outcomes [35]. Considering that procurement strategies involve series of decision-making, clients need to establish standardised procedures and methods to integrate and achieve the desired objectives. Within each procurement stage, there are a variety of different alternatives that can be used to deliver the project. However, each of the available alternatives may achieve the project objectives in varying ways. Therefore, before deciding on which strategy to adopt, clients need to obtain adequate information and evaluate the degree to which the identified alternatives can help in achieving the set objectives.

\subsection{Integration of Theories into Theoretical Framework}

In proposing a theoretical framework (see Figure 1), IIT has been enriched with rational decision-making to justify that when construction clients prioritise H\&S matters and carefully integrate them into their procurement decision-making process, it improves H\&S implementation on the project. The nature of IIT suggests that H\&S must be treated 
as an important and valuable objective and must be well considered in the decisionmaking process.

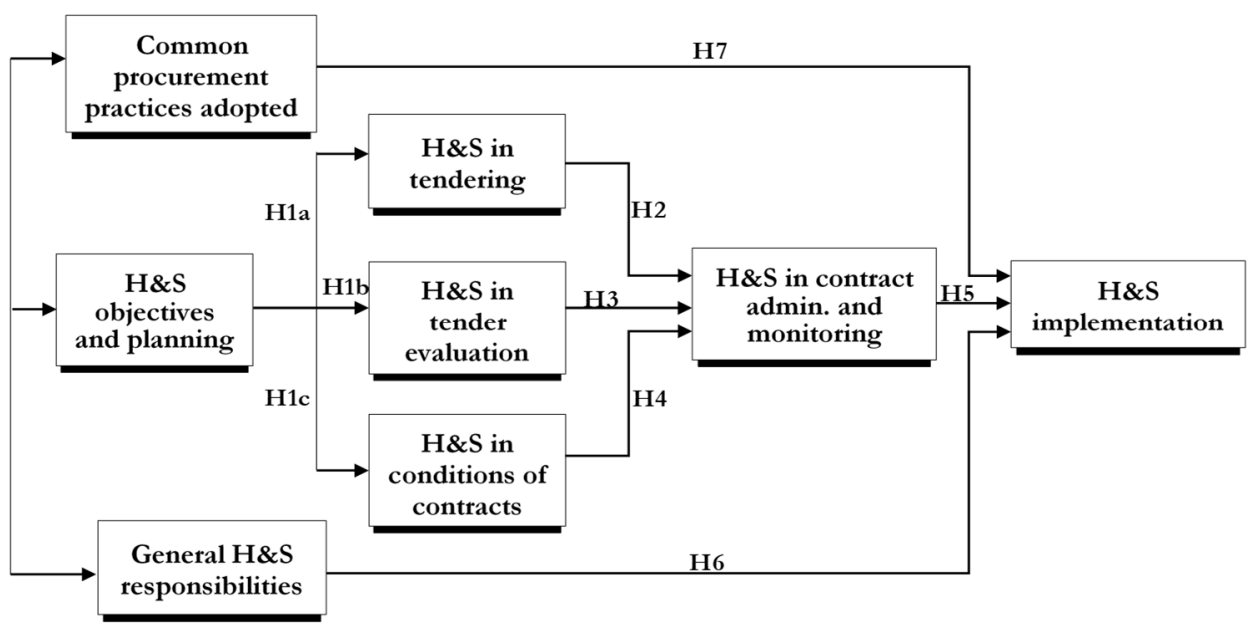

Figure 1. Theoretical model for considering H\&S in construction procurement.

Figure 1 shows the proposed theoretical relationships for considering H\&S issues in the procurement process. The model has specified a hypothesised cause and effect relationship that exists among the various indicators and determines the extent of direct and indirect effects that an indicator has on the others, as shown by the arrows. The model has been developed to reflect the chronology in the construction procurement process; it follows the stages including planning (including project objectives), tendering, tender evaluation and contract award, conditions of contract, and contract administration and monitoring, respectively. This is consistent with the stages of construction procurement outlined by Boadu et al. [14] and Akintoye and Main [18].

The model generally suggests that promoting H\&S through the procurement process starts with establishing clear objectives relating to $\mathrm{H} \& \mathrm{~S}$ and planning towards their implementation on projects. Consequently, these established objectives would influence subsequent procurement decisions such as those made in the tendering stage, tender evaluation and in preparing the conditions of contract for the project. It is predicted that the decisions made in these three stages will impact on the way the contract for the project is administered and monitored by the clients or their representatives. Ultimately, the way the contract is administered and monitored with respect to H\&S matters would affect the H\&S implementation within the project. Again, the model predicts that the clients' general responsibilities and attitude towards H\&S and the adoption of common procurement practices would influence $H \& S$ implementation on projects.

Specifically, the proposed model hypothesised the following.

i. H\&S objectives and planning will influence the H\&S considerations and decisions made during tendering ( $\mathrm{H} 1 \mathrm{a})$, tender evaluation $(\mathrm{H} 1 \mathrm{~b})$, and conditions of contracts (H1c). This hypothesis assumes that H\&S is regarded as an important project objective and thus receives adequate consideration in the procurement decision-making. This is premised on the theoretical foundation that decision makers enter decision conditions with clearly defined objectives and these objectives determine the possible course(s) of action and outcomes.

ii. H\&S considerations and decisions made in the tendering phase will influence contract administration and monitoring regarding $\mathrm{H} \& \mathrm{~S}$ (H2). Reasonably, an adequate consideration of H\&S issues in tendering may result in the establishment and communication of appropriate $H \& S$ requirements through the tender documents to prospective contractors. Thus, it is presumed that the H\&S requirements and considerations will subsequently impact on the way the projects would be monitored for H\&S implementation. 
iii. Tender evaluation decisions taken with regards to H\&S will impact on contract administration and monitoring (H3). This is premised on the basis that tenders are usually evaluated based on criteria linked to the project objectives. Thus, depending on the extent (weight) of H\&S consideration among the evaluation criteria, the contract for the project will be administered and monitored to ensure that the H\&S objective is achieved.

iv. The H\&S provisions made in the conditions of contract will influence contract administration and monitoring $(\mathrm{H} 4)$. Generally, conditions of contract provide the terms of agreement and set the rights and obligations of all the contracting parties. Therefore, conditions of contract which clearly expresses adequate standards and obligations relating to $\mathrm{H} \& \mathrm{~S}$ for contractors provide a good contractual basis for the client to administer and monitor the H\&S implementation on the project.

v. Contract administration and monitoring on H\&S issues will affect the extent of H\&S implementation on the project (H5). Contract administration and monitoring aims to ensure that contractors, subcontractors, and all other project participants comply with the contract conditions and execute the project in accordance with the requirements and specifications. Thus, it is hypothesised that an adequate level of contract administration and monitoring in relation to H\&S implementation will ensure that contractors perform their tasks safely, thereby achieving good H\&S implementation on the project.

vi. Clients' general responsibilities and attitudes towards H\&S will impact on the extent of H\&S implementation on their projects (H6). It is acknowledged that clients make the key project decisions including budget, schedule, quality, and other performance criteria, and all these have consequences for H\&S management on the project. Therefore, it is assumed that if clients consider H\&S as a crucial responsibility and demonstrate tangible commitment to the development of positive safety culture in their own organisations and on their projects, it will go a long way to impact on the H\&S implementation on their projects.

vii. Adopting procurement practices because of familiarity or popularity may influence H\&S implementation on projects (H7). The procurement processes provide a good opportunity to integrate objectives relevant to the project. An efficient procurement approach is considered as a key determinant of project success as it incorporates the desired project objectives. Likewise, failure to choose an appropriate procurement approach based on the desired objectives can cause project dissatisfaction [21]. Based on the above rationale, it is assumed that choosing a procurement approach based on its popularity or familiarity to the client, and not on the desired objectives (such as $H \& S)$, will ultimately affect $H \& S$ implementation on the project.

\section{Model Generation}

\subsection{Data Collection, Analysis, and Evaluation}

Firstly, a hypothesised model has been developed based on the construction procurement literature [19,24], and on the theoretical concepts of IIT [25] and decision-making [31] to explain that if construction clients deem H\&S objectives as an important or priority project objective, they will consider H\&S issues in an adequate manner when making decisions within the procurement process, and this will ultimately impact on the project $H \& S$ implementation. Basically, the IIT suggests that an individual's attitude is largely shaped by information that is valuable and important to them. The rational decision-making concept also posits that a decision-maker makes choice(s) among different alternatives based on a set of objectives and achieves outcomes that are aligned with the objectives. Thus, the model assumes that once the H\&S objective is deemed important and hence, prioritised, it would receive adequate consideration in decision-making in the various procurement stages, and eventually improve H\&S.

Following the hypothesised model, an empirical analysis was conducted using data collected through a quantitative research approach. This approach is considered appropri- 
ate to verify a theory or to determine the truth or otherwise of hypotheses or theories [36]. The instrument used in this study was developed by considering the extent of H\&S integration into decision-making and practices in the various stages of the procurement process. Through reflective measurement models, the various constructs were operationalised. As recommended by Chin et al. [37], the latent constructs were operationalised based on three or more indicators, wherever possible.

To be assured that the sampled participants could inform important facets of the study, the sampling frame involved a population of construction industry professionals in Ghana who had direct involvement in the project procurement process. The participants were selected through convenience sampling because it presented an efficient method to reach the sampled population. Although convenience sampling may be prone to selection bias and lack of representation of population, the participants were drawn from different types of organisations, namely, consultants, contractors, construction clients, trade unions/associations, and suppliers. The participants were also spread throughout Ghana, with various professional backgrounds and different levels of construction industry experience.

Following the recommendation of Daniel [38], an adequate sample size was determined. The demographic profile of respondents has been given in Table 1. Both online and paper-based questionnaires (a total of 720) were distributed to the sampled population, and 287 complete responses were received from the participants. This represents a relatively high response rate of almost $40 \%$, given that the response rate in construction management research is usually low [39]. The questionnaire (see Appendix A) sought the views of respondents on the extent of $H \& S$ consideration in the various stages of the procurement process for public construction projects in Ghana and the general perception of the extent of H\&S implementation on those projects. A Likert scale ranging from 1-5, where $1=$ strongly disagree, $2=$ disagree, $3=$ neutral, $4=$ agree, and $5=$ strongly agree, was used to guide respondents.

Table 1. Demographic profile of respondents.

\begin{tabular}{|c|c|c|c|c|}
\hline$S / n$ & Parameter & Category & Frequency & Percentage $(\%)$ \\
\hline \multirow{9}{*}{1.} & \multirow{9}{*}{ Age (in years) } & $18-25$ & 15 & 5.23 \\
\hline & & $26-30$ & 47 & 16.38 \\
\hline & & $31-35$ & 52 & 18.12 \\
\hline & & $36-40$ & 63 & 21.95 \\
\hline & & $41-45$ & 42 & 14.63 \\
\hline & & $46-50$ & 36 & 12.54 \\
\hline & & $51-55$ & 23 & 8.01 \\
\hline & & $56-60$ & 7 & 2.44 \\
\hline & & Above 60 & 2 & 0.70 \\
\hline \multirow{5}{*}{2.} & \multirow{5}{*}{ Years of work experience } & $1-5$ & 65 & 22.65 \\
\hline & & $6-10$ & 66 & 23.00 \\
\hline & & $11-15$ & 67 & 23.34 \\
\hline & & $16-20$ & 57 & 19.86 \\
\hline & & Above 20 years & 32 & 11.15 \\
\hline \multirow{5}{*}{3.} & \multirow{5}{*}{ Nature of organisation } & Consultant & 88 & 30.66 \\
\hline & & Contractor & 87 & 30.31 \\
\hline & & Government & 104 & 36.24 \\
\hline & & Supplier & 5 & 1.74 \\
\hline & & $\begin{array}{l}\text { Industry/trade } \\
\text { union }\end{array}$ & 3 & 1.05 \\
\hline
\end{tabular}

In line with ethical considerations, the survey was accompanied by a cover letter and participant information statement and consent form (PISCF) which outlined the objectives of the research and the risks associated with participation. Participants were required to acquaint themselves with the information in the PISCF before consenting to participate 
in the study. Furthermore, the participants were assured of their confidentiality and anonymity, and also that they could withdraw from the study at any time.

In this research, path analysis is used to illustrate the relationship structure between the constructs and to test the hypotheses. Path analysis has been used extensively in research to explain causal relationships between variables. The proposed structural model was developed by considering the theoretical foundations of issues that can promote H\&S through the procurement process. As discussed in the theoretical framework underpinning the research, the indicators for promoting $H \& S$ in procurement include setting and integrating clear objectives relating to $\mathrm{H} \& \mathrm{~S}$ and considering $\mathrm{H} \& \mathrm{~S}$ issues in the subsequent procurement decisions, such as project planning, tendering, tender evaluation and contract award, conditions of contract, and contract administration and monitoring.

Prior to performing the path analysis, preliminary analysis such as distribution characteristics, common method bias, and model identification were performed on the data to determine the appropriateness of the data for path analysis. Subsequently, the measurement model was evaluated to determine the reliability and validity of the constructs. This section presents the final measurement model, and the model fit indices.

\subsubsection{Preliminary Data Analysis}

It was essential to determine the distribution characteristics of the data before conducting the path analysis to verify the normality of the data because the data distribution effects the selection of estimation method [40] and non-normal data can cause problems when evaluating the significance of parameters [41]. Therefore, skewness and kurtosis were evaluated to establish the normality of the data. According to Byrne [42], if skewness values range between -2 and +2 and the kurtosis values fall between -7 and +7 , then the assumption of data normality is determined to be fulfilled. The results indicated that both skewness and kurtosis ( -0.35 to 0.73 and -1.15 to -0.05 , respectively) were within the acceptable limits, and thus, there were no issue with non-normality of data.

Again, the Harman's single-factor test was used to determine whether common method bias existed in the data, so as to tackle self-reporting issues from the questionnaire. After performing the maximum likelihood factor analysis on the various procurement stage $\mathrm{H} \& \mathrm{~S}$ considerations, the results showed that no single factor accounted for $50 \%$ or more of the variance. This indicated that the common method bias or variance was not a concern.

In addition, it was important to ascertain whether the proposed model could be analysed or not. This required model identification checks to determine whether the proposed model was over-identified, just-identified, or under-identified. Generally, for a proposed model to be analysed, the degrees of freedom resulting from the difference between the number of data points and the number of parameters to be estimated should be greater than zero [43]. The proposed model in this study had degrees of freedom equal to $234(\mathrm{df}=234)$, which indicates that the model is over-identified and thus suitable for analysis.

\subsubsection{Evaluation of Measurement Model}

Before performing the analysis, one key initial step was to develop a measurement model and evaluate it. The measurement model specifies the relationship between measured and latent variables [44]. In structural equation modelling (SEM), the two main criteria used to evaluate the measurement model are reliability and validity [45]. While reliability measures the stability and consistency of indicators, validity tests evaluate how accurately an indicator measures a particular construct that it is designed to measure [43] To evaluate reflective measurement models, internal consistency reliability and convergent and discriminant validity must be established [46]. 


\section{Internal Consistency Reliability}

Internal consistency assesses whether different indicators that measure the same construct produce similar scores. It measures the quality of a construct, and it requires a high extent of correlation between the indicators of a construct [47]. Internal consistency reliability is measured by the Cronbach's alpha or composite reliability. When the Cronbach's alpha value is 0.7 or higher, the internal consistency reliability of a construct is assumed to be fulfilled [48]. Like Cronbach's alpha, composite reliability also ranges between 0 and 1 , with higher values suggesting higher levels of reliability [49].

In Table 2, the results of internal consistency reliability including the Cronbach's alpha and composite reliability are presented. The results show that aside from the common practices construct, all the remaining constructs had high levels of internal consistency reliability. This demonstrates that the measurement indicators were suitable for their respective constructs. It is worth noting that the implementation construct (PER) is a single-indicator construct and thus the composite reliability value is 1.00; but this does not necessarily mean that the constructs exhibit perfect reliability [50].

\section{Convergent Validity}

The convergent validity is assessed by evaluating the factor loadings of the individual indicators and to determine the average variance extracted (AVE) for each construct. Higher significant outer loadings on a construct demonstrate that the indicators have much in common and they are appropriately explained by the construct [51]. As a guideline, and as used by many researchers, an outer loading of 0.708 and greater is recommended to retain a measurement indicator $[52,53]$. Another measure of the convergent validity is the average variance extracted (AVE). As a rule of thumb, an AVE $>0.50$ is required for adequate convergence.

The results of the convergent validity consisting of factor loadings and AVE have also been presented in Table 2. Based on the rule of thumb, all the indicators with loading less than 0.708 were eliminated, after conducting an iterative evaluation using the SPSS Amos 26 Graphics software. In all, 15 indicators comprising 2 indicators from the objectives and planning construct, 2 from the tendering construct, 1 from the conditions of contract construct, 2 from the contract administration and monitoring construct, 3 from the general responsibilities construct, and all the 5 indicators from the common procurement practices construct were eliminated. Thus, a total of 24 indicators were retained to be used to evaluate the measurement model. The descriptions of the indicators (both retained and eliminated) are given in Tables 3 and 4 .

Moreover, the results showed that the values for AVE generated for the retained constructs were above the required minimum level of 0.5 . This means that these constructs have high levels of convergent validity. However, the common procurement practices construct had an AVE value less than the required minimum level. Therefore, based on the poor outer loadings of the indicators and inadequate AVE, the common procurement practices construct was entirely removed from the measurement model. Again, it is worth noting that the single-indicator construct (PER1) does not have values for the internal consistency reliability and convergent validity measures such as Cronbach's alpha and AVE because these measures are not applicable to single-indicator constructs [50].

\section{Discriminant Validity}

Discriminant validity is aimed at ensuring that a measure of a construct is empirically distinct and not captured by other constructs in a SEM [44]. This means that for discriminant validity to be achieved, it is required that a construct measure must not be too highly correlated with measures from a differing construct [43]. The study adopted the HTMT criterion to evaluate the discriminant validity. Generally, an HTMT value close to 1 suggests the lack of discriminant validity.

The results of the HTMT criterion for discriminant validity assessment are presented in Table 5. From the table, the results show that: 
- 9 out of the 15 comparisons violated the $\mathrm{HTMT}_{0.85}$ criterion

- 3 out of the 15 comparisons violated the $\mathrm{HTMT}_{0.90}$ criterion

- The HTMT $\mathrm{H}_{\text {inference }}$ indicated that all the 15 comparisons have fulfilled the assumption of discriminant validity between all the construct measures.

Table 2. Reliability and validity of constructs.

\begin{tabular}{|c|c|c|c|c|c|}
\hline Construct & Indicator & Loading & Cronbach's Alpha & CR & AVE \\
\hline \multirow{10}{*}{$\begin{array}{l}\text { H\&S objectives } \\
\text { and planning }\end{array}$} & OPL1 & 0.748 & \multirow{10}{*}{$\begin{array}{l}\theta .930 \\
0.930\end{array}$} & \multirow{10}{*}{$\begin{array}{l}0.927 \\
0.927\end{array}$} & \multirow{10}{*}{$\begin{array}{l}0.564 \\
0.614\end{array}$} \\
\hline & OPL2 & 0.754 & & & \\
\hline & OPL3 & 0.787 & & & \\
\hline & ӨP 44 & $\theta .529$ & & & \\
\hline & ӨPL5 & $\theta .671$ & & & \\
\hline & OPL6 & 0.815 & & & \\
\hline & OPL7 & 0.792 & & & \\
\hline & OPL8 & 0.743 & & & \\
\hline & OPL9 & 0.832 & & & \\
\hline & OPL10 & 0.792 & & & \\
\hline \multirow{5}{*}{ H\&S in tendering } & TEN1 & $\theta .679$ & \multirow{5}{*}{$\begin{array}{l}\theta .861 \\
0.845\end{array}$} & \multirow{5}{*}{$\begin{array}{l}\theta .863 \\
0.835\end{array}$} & \multirow{5}{*}{$\begin{array}{l}0.558 \\
0.627\end{array}$} \\
\hline & TEN2 & 0.758 & & & \\
\hline & TEN3 & 0.818 & & & \\
\hline & TEN4 & $\begin{array}{l}0.010 \\
0.799\end{array}$ & & & \\
\hline & TEN5 & 0.669 & & & \\
\hline \multirow{5}{*}{ H\&S in tender evaluation } & TEV1 & 0.800 & \multirow{5}{*}{0.903} & \multirow{5}{*}{0.905} & \multirow{5}{*}{0.655} \\
\hline & TEV2 & 0.838 & & & \\
\hline & TEV3 & 0.776 & & & \\
\hline & TEV4 & 0.827 & & & \\
\hline & TEV5 & 0.805 & & & \\
\hline \multirow{4}{*}{$\begin{array}{l}\text { H\&S in conditions } \\
\text { of contract }\end{array}$} & EOC1 & 0.707 & \multirow{4}{*}{$\begin{array}{l}\theta .849 \\
0.841\end{array}$} & \multirow{4}{*}{$\begin{array}{l}\theta .853 \\
0.832\end{array}$} & \multirow{4}{*}{$\begin{array}{l}0.593 \\
0.624\end{array}$} \\
\hline & COC2 & 0.850 & & & \\
\hline & $\mathrm{COC} 3$ & 0.774 & & & \\
\hline & COC4 & 0.741 & & & \\
\hline \multirow{4}{*}{$\begin{array}{l}\text { H\&S in contract } \\
\text { administration and } \\
\text { monitoring }\end{array}$} & MON1 & 0.807 & \multirow{4}{*}{$\begin{array}{l}0.822 \\
0.849\end{array}$} & \multirow{4}{*}{$\begin{array}{l}0.825 \\
0.814\end{array}$} & \multirow{4}{*}{$\begin{array}{l}0.546 \\
0.687\end{array}$} \\
\hline & MON2 & 0.850 & & & \\
\hline & MON3 & 0.594 & & & \\
\hline & MON4 & $\theta .677$ & & & \\
\hline \multirow{5}{*}{$\begin{array}{l}\text { General H\&S } \\
\text { responsibilities }\end{array}$} & GEN1 & 0.365 & \multirow{5}{*}{$\begin{array}{l}0.792 \\
0.799\end{array}$} & \multirow{5}{*}{$\begin{array}{l}0.800 \\
0.754\end{array}$} & \multirow{5}{*}{$\begin{array}{l}0.457 \\
0.606\end{array}$} \\
\hline & GEN2 & 0.757 & & & \\
\hline & GEN3 & 0.799 & & & \\
\hline & GEN4 & $\theta .675$ & & & \\
\hline & GEN5 & $\theta .697$ & & & \\
\hline \multirow{5}{*}{$\begin{array}{l}\text { Common procurement } \\
\text { practices }\end{array}$} & EPP1 & $\theta .668$ & \multirow{5}{*}{0.603} & & \\
\hline & CPPZ & 0.338 & & & \\
\hline & СPP3 & 0.538 & & 0.707 & 0.336 \\
\hline & EPP4 & $\theta .660$ & & & \\
\hline & EPP5 & $\theta .627$ & & & \\
\hline H\&S implementation & PER1 & 1.000 & & 1.000 & \\
\hline
\end{tabular}

Note: E.g., ӨP५4 - indicator deleted, and 9.930 -value of reliability before deleted indicator.

Adopting the more liberal $\mathrm{HTMT}_{\text {inference }}$ indicated that discriminant validity was achieved. The choice of the HTMT $\mathrm{H}_{\text {inference }}$ was influenced by the model set-up and how liberal the researcher is in the assessment of discriminant validity [54]. Considering that the constructs in this study are all related to one process (the procurement process), it would be difficult to differentiate them empirically because they are conceptually highly similar. Thus, the choice of the $\mathrm{HTMT}_{\text {inference, }}$ which is a more liberal criterion, is appropriate under these conditions. 
Table 3. Indicators retained and used in path analysis model.

\begin{tabular}{|c|c|c|}
\hline Construct & Indicator & Indicator Description \\
\hline \multirow{8}{*}{ H\&S objectives and planning } & OPL1 & Setting H\&S objectives/targets \\
\hline & OPL2 & Prioritising H\&S objectives \\
\hline & OPL3 & Effectively communicating H\&S objectives \\
\hline & OPL6 & Developing project risk register \\
\hline & OPL7 & Considering H\&S in the choice of design option \\
\hline & OPL8 & Allocating $\mathrm{H} \& \mathrm{~S}$ in project budget \\
\hline & OPL9 & Setting H\&S standard for prospective contractors \\
\hline & OPL10 & Considering H\&S in choice of procurement method \\
\hline \multirow{3}{*}{$\mathrm{H} \& \mathrm{~S}$ in tendering } & TEN2 & Clearly specifying H\&S issues in tender \\
\hline & TEN3 & Including H\&S regulations \& standards in tender \\
\hline & TEN4 & Assigning adequate weighting to $H \& S$ \\
\hline \multirow{5}{*}{$\mathrm{H} \& \mathrm{~S}$ in tender evaluation } & TEV1 & Including H\&S costs in project estimates (BOQ) \\
\hline & TEV2 & Including H\&S expert on tender evaluation panel \\
\hline & TEV3 & Doing due diligence on contractors H\&S submissions \\
\hline & TEV4 & Rejecting tenders which do not meet H\&S requirements \\
\hline & TEV5 & Making H\&S one of the key criteria for contract award \\
\hline \multirow{3}{*}{ H\&S in conditions of contract } & COC2 & Developing specific conditions to deal with H\&S \\
\hline & COC3 & Prescribing penalties for H\&S breaches \\
\hline & COC4 & Considering H\&S in contract negotiation \\
\hline \multirow{2}{*}{$\begin{array}{l}\text { H\&S in contract administration and } \\
\text { monitoring }\end{array}$} & MON1 & Collecting periodic reports on $\mathrm{H} \& S$ \\
\hline & MON2 & Using H\&S targets to track performance \\
\hline \multirow{2}{*}{ General H\&S responsibilities } & GEN2 & Understanding of H\&S responsibility on projects \\
\hline & GEN3 & Assuming full responsibility for $\mathrm{H} \& \mathrm{~S}$ \\
\hline H\&S implementation & PER1 & Good H\&S implementation on projects \\
\hline
\end{tabular}

Table 4. Indicators eliminated due to poor loading.

\begin{tabular}{|c|c|c|}
\hline Construct & Indicator & Indicator Description \\
\hline \multirow{2}{*}{ H\&S objectives and planning } & OPL4 & Checking designers for H\&S competence \\
\hline & OPL5 & Expressing H\&S in designers' contract \\
\hline \multirow{2}{*}{ H\&S in tendering } & TEN1 & Considering H\&S in choice of tendering method \\
\hline & TEN5 & Considering H\&S as key criteria for shortlisting \\
\hline H\&S in conditions of contract & COC1 & Adequate $\mathrm{H} \& S$ provisions in standard form of contract \\
\hline \multirow{2}{*}{$\begin{array}{l}\text { H\&S in contract administration } \\
\text { and monitoring }\end{array}$} & MON3 & Taking actions to improve H\&S when prompted \\
\hline & MON4 & Requiring subcontractors to be H\&S competent \\
\hline \multirow{3}{*}{ General H\&S responsibilities } & GEN1 & Established H\&S policy \\
\hline & GEN4 & Reimbursing contractors' $\mathrm{H} \& \mathrm{~S}$ costs \\
\hline & GEN5 & Evaluation of $\mathrm{H} \& S$ performance on projects \\
\hline \multirow{5}{*}{ Common procurement practices } & CPP1 & Traditional procurement method is commonly used \\
\hline & CPP2 & Competitive tendering is usually adopted \\
\hline & CPP3 & Clients keep preferred list of contractors \\
\hline & $\mathrm{CPP} 4$ & Standard forms of contract are usually adopted \\
\hline & CPP5 & In-house staff is usually designated to monitor project \\
\hline
\end{tabular}

Final Measurement Model

Following the results obtained for the internal consistency reliability, convergent validity, and discriminant validity, it could be concluded that the measurement model was within acceptable range. In Figure 2 the measurement model is shown in detail by including the individual indicator loading to the respective constructs, as well as the other reliability and validity measurements. Given that the measurement model was within 
acceptable range, it has shown the required robustness to test the relationship between the constructs using the path analysis technique.

Table 5. HTMT criterion for discriminant validity.

\begin{tabular}{|c|c|c|c|c|c|c|}
\hline & OPL & TEN & TEV & $\mathrm{COC}$ & MON & GEN \\
\hline OPL & & & & & & \\
\hline TEN & $\begin{array}{c}0.944 \\
\mathrm{CI}[0.910 ; 0.977]\end{array}$ & & & & & \\
\hline TEV & $\begin{array}{c}0.876 \\
\text { CI[0.834;0.915] }\end{array}$ & $\begin{array}{c}0.870 \\
\text { CI[0.808;0.925] }\end{array}$ & & & & \\
\hline $\mathrm{COC}$ & $\begin{array}{c}0.920 \\
\text { CI[0.872;0.965] }\end{array}$ & $\begin{array}{c}0.893 \\
\text { CI[0.834;0.950] }\end{array}$ & $\begin{array}{c}0.960 \\
\text { CI[0.924;0.989] }\end{array}$ & & & \\
\hline MON & $\begin{array}{c}0.827 \\
\text { CI[0.760;0.886] }\end{array}$ & $\begin{array}{c}0.824 \\
\text { CI[0.752;0.888] }\end{array}$ & $\begin{array}{c}0.841 \\
\text { CI[0.767;0.906] }\end{array}$ & $\begin{array}{c}0.885 \\
\text { CI[0.816;0.949] }\end{array}$ & & \\
\hline GEN & $\begin{array}{c}0.873 \\
\mathrm{CI}[0.782 ; 0.947]\end{array}$ & $\begin{array}{c}0.862 \\
\text { CI[0.767;0.948] }\end{array}$ & $\begin{array}{c}0.766 \\
\text { CI[0.660;0.856] }\end{array}$ & $\begin{array}{c}0.828 \\
\text { CI[0.718;0.920] }\end{array}$ & $\begin{array}{c}0.726 \\
\mathrm{CI}[0.604 ; 0.833]\end{array}$ & \\
\hline
\end{tabular}

Note: CI refers to confidence interval and it was obtained by running the bootstrapping routine in SmartPLS.

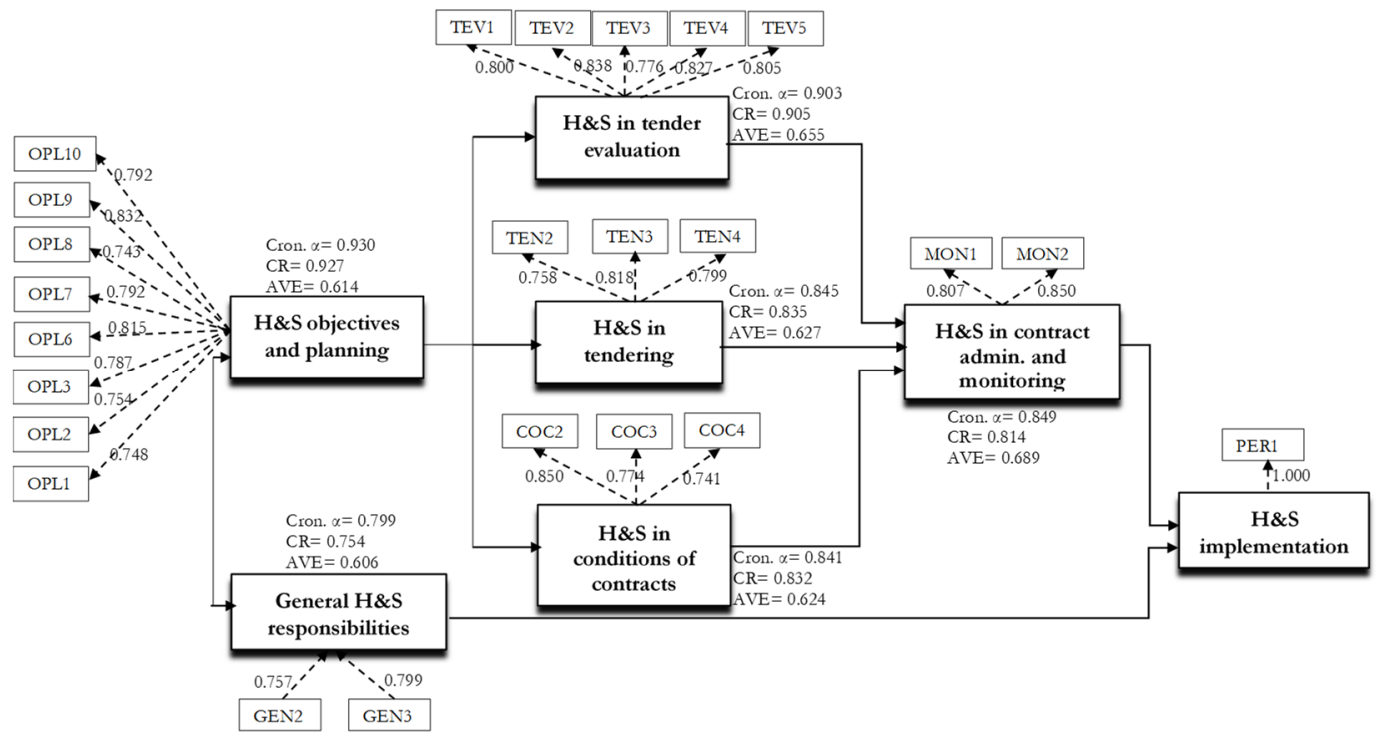

Figure 2. Measurement model with loadings.

\section{Model Fit Indices}

Generally, a model fit is defined as the ability of the model to reproduce the data. Thus, a model which is reasonably consistent with the data is a good-fitting model and may not be required to be respecified [55]. Table 6 presents the model fit indices for the proposed model. The data sample for the model produced a chi-square value of 502.48 with 234 degrees of freedom, resulting in a significant $p$-value (0.000). Although the cut-off for good fit requires a $p$-value $>0.5$, it is important to note that the chi-square is sensitive to sample size and thus could not be relied upon to demonstrate fit. Using the ratio of the chi-square to the degrees of freedom produced a value of 2.15, which is lower than the recommended upper limit value of 3.0, and this demonstrates a good model fit. 
Table 6. Model fit indices summary.

\begin{tabular}{|c|c|c|c|}
\hline Fit Index & Value Obtained & Cut-Off Value & Remarks \\
\hline Chi-square & 502.48 & & \\
\hline $\begin{array}{l}\text { Degrees of freedom } \\
\text { (df) }\end{array}$ & 234 & $\geq 0$ & Acceptable \\
\hline Chi-square/df & 2.15 & $\begin{array}{l}\leq 3, \text { good } \\
\leq 5, \text { acceptable }\end{array}$ & Good \\
\hline Probability level & 0.000 & $>0.5$ & Inadequate \\
\hline RMSEA & 0.063 & $\begin{array}{l}\leq 0.05, \text { good } \\
\leq 0.08, \text { acceptable }\end{array}$ & Acceptable \\
\hline GFI & 0.869 & $\begin{array}{l}\geq 0.95, \text { good } \\
\geq 0.90, \text { acceptable }\end{array}$ & Inadequate \\
\hline AGFI & 0.831 & $\begin{array}{l}\geq 0.95, \text { good } \\
\geq 0.80, \text { acceptable }\end{array}$ & Acceptable \\
\hline RMR & 0.042 & $\begin{array}{l}\leq 0.05, \text { good } \\
\leq 0.08, \text { acceptable }\end{array}$ & Good \\
\hline NFI & 0.912 & $\begin{array}{l}\geq 0.95, \text { good } \\
\geq 0.90, \text { acceptable }\end{array}$ & Acceptable \\
\hline TLI & 0.942 & $\begin{array}{l}\geq 0.95, \text { good } \\
\geq 0.90, \text { acceptable }\end{array}$ & Acceptable \\
\hline CFI & 0.951 & $\begin{array}{l}\geq 0.95, \text { good } \\
\geq 0.90, \text { acceptable }\end{array}$ & Good \\
\hline
\end{tabular}

Other fit indices that were used to assess the model included the root mean square error of approximation (RMSEA), goodness of fit (GFI), adjusted goodness of fit (AGFI), root mean square residual (RMR), normed fit index (NFI), Tucker Lewis index (TLI) and the comparative fit index (CFI). From the results in Table 6, all the indices except GFI demonstrated that the model met the conditions for acceptance. Therefore, it could be concluded that the model was a good-fitting one and as such the path analysis could be performed to determine the magnitude of the direct and indirect relationships that existed between the constructs.

\section{Results and Discussions}

The model postulates that procurement processes could be used to promote H\&S on construction projects by integrating H\&S objectives into the procurement decisions at the planning and tendering stages, during tender evaluation, in preparing conditions of contract, and in administering and monitoring contracts. As seen from the final measurement model section, the indicators of the various constructs have been analysed using SEM. As such the final model (see Figure 3 ) has been made concise by removing the indicators from the constructs in order to present a clear, uncomplicated, and orderly network of relationships which would be easy to understand.

The results of the path analysis are presented in Figure 3. The entire relationship started with setting the project objectives and the plans that were put in place to realise the set of objectives. Thus, the set of objectives in effect established overarching performance requirements for the procurement process [20]. In the context of this research, H\&S was considered as an important issue and as such clients were required to develop and integrate (into the overall project objectives) clear H\&S requirements and standards that they expected to achieve on their projects. These objectives would then form the basis for decision-making throughout the procurement process. The results of the path analysis including the hypotheses are discussed below: 


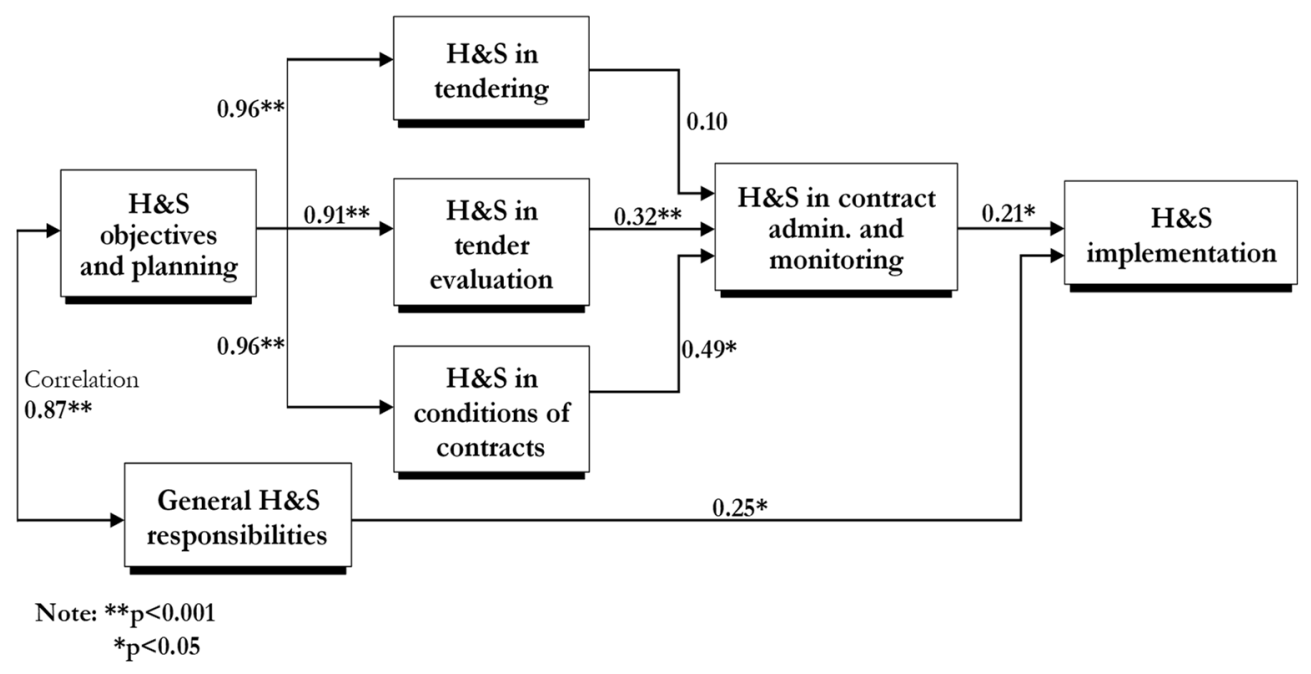

Figure 3. Model for promoting H\&S through the procurement process.

Hypothesis 1a (H1a). HES objectives and planning will influence the HES considerations and decisions made during tendering.

Based on the model in Figure 3, setting clear objectives relating to H\&S strongly predicts the extent to which H\&S issues will be considered in the tendering process (significant coefficient 0.96 ). Clearly, this suggests that clients who regard H\&S as an important project objective would sufficiently incorporate H\&S issues into the tendering process. The tendering stage activities afford clients the opportunity to explicitly specify H\&S requirements in the tender documentation. Though the tender process is acknowledged to be complex, challenging, and beset with many uncertainties [56], with clearly defined objectives and planning, the required tender documentation and processes could be put in place to achieve the desired H\&S outcomes. The need to achieve the project's H\&S objectives would heighten the need for the client to fully consider H\&S issues in the tender process. For instance, if a client called for tenders and clearly communicated the way in which prospective tenderers should treat $\mathrm{H} \& S$ matters in their tenders, then all tendering contractors would be obligated to make appropriate allocations for H\&S in their offers, as specified in the tender documentation. This would assist the client to identify and compare the H\&S competences of all the contractors and accordingly, eliminate unscrupulous ones [57].

Hypothesis $\mathbf{1 b}(\mathbf{H} 1 \mathbf{b})$. HES objectives and planning will influence the HES considerations and decisions made during tender evaluation.

H\&S objectives are a strong predictor of the extent to which H\&S matters would be considered in the tender evaluation stage (significant coefficient 0.91). Traditionally, selecting a competent and experienced contractor is a key step towards achieving project objectives. The tender evaluation phase assists clients to make this key decision, which may influence the success or otherwise of the project. This is because a competent contractor is likely to complete the project within the set objectives. On the other hand, the selection of a wrong contractor may lead to increased project risks such as delays, reworks, accidents, and poor quality of work, among others. Therefore, tender evaluation which leads to the selection of the contractor must emphasise the capabilities and experience of the contractor to deliver the project objectives. Mindful of the above reasons, clients who set and prioritise H\&S objectives would want to appoint contractor(s) who can fulfil that project objective. The criteria for contractor selection ensure that clients are presented with standards of judgement, and rankings of priority indicators that will be used to assess tender offers and select the suitable contractor out of the lot in order to achieve the desired 
objectives [58]. Typically, the evaluation criteria must reflect the project objectives [59]. This means that clients who prioritise $H \& S$ objectives on their projects will ultimately set and place a premium on H\&S indicators in tender evaluation to ensure that H\&S is adequately considered in the choice of contractor. In this way, the client can be assured that the selected contractor has sufficient capabilities to fulfil the project's H\&S objectives.

Hypothesis 1c (H1c). HES objectives and planning will influence the HES considerations in the conditions of contracts.

Figure 3 shows that setting clear H\&S objectives can strongly influence the specification of $\mathrm{H} \& \mathrm{~S}$ provisions in the conditions of contract in an adequate manner (significant coefficient 0.96). A contract, by definition, is a legally binding agreement; as such, when $\mathrm{H} \& S$ requirements are appropriately set up in a contract, the contractor is obligated to perform accordingly. Thus, adequate specification of H\&S requirements in contracts is essential in order to communicate the client's commitment to the project $\mathrm{H} \& \mathrm{~S}$ objectives and also to indemnify the client if the contractors fail to perform their H\&S obligations under the contract. This suggests that even when a client adopts standard forms of contracts, which mostly do not adequately specify H\&S issues [60], the client will purposely develop specific clauses relating to H\&S so as to drive home the need to achieve the H\&S objectives. Such contract conditions may prescribe incentive and/or penalty clauses for good and poor H\&S implementation, respectively.

Correlation between project HES objectives and clients' general responsibilities towards HES.

From Figure 3, there is a strong positive correlation between these two constructs (significant coefficient 0.87 ). Essentially, this relationship suggests that clients who set H\&S objectives for their projects are likely to take their responsibility towards H\&S implementation seriously and vice versa. The client determines the overall project objectives and undoubtedly is the most influential stakeholder responsible for controlling the direction of the project [57]. Thus, the overall success in achieving the project objectives including $H \& S$ is directly related to the extent to which the client assumes responsibility for the implementation of these objectives. Generally, there are some prescribed statutory H\&S responsibilities, as well as ethical obligations that clients need to fulfil. These statutory and ethical responsibilities are not taken away from the client when the project is outsourced to contractors [12]. Therefore, in taking reasonable steps to ensure that they assume their responsibilities for H\&S implementation on projects, the client may begin by setting clear objectives relating to $H \& S$ and work towards achieving them. Essentially, by setting clear $H \& S$ objectives and planning towards their implementation, clients demonstrate their commitment to H\&S and comply with their responsibilities.

Hypothesis 2 (H2). HES considerations and decisions made in the tendering phase will influence contract administration and monitoring regarding HES.

The result does not support this hypothesis (non-significant coefficient 0.10). This finding largely suggests that though an adequate consideration of $H \& S$ in the tendering stage may result in the specification of H\&S requirements to prospective contractors, it may not directly influence the administration and monitoring of the contract relative to H\&S implementation.

Hypothesis 3 (H3). Tender evaluation decisions taken with regards to HES will impact on contract administration and monitoring.

Figure 3 indicates further that the extent of H\&S considerations in tender evaluation may significantly influence the extent of contract administration and monitoring regarding $H \& S$ (significant coefficient 0.32 ). Tender evaluation helps to reveal the most suitable tenderer based on the evaluation criteria used. Hence, any contractor who is selected based on their demonstrated competence in respect of the evaluation criteria is expected to 
perform on the job accordingly. For instance, if a client selects a contractor who, among other things, prescribed in a tender submission that it would use specific safe systems of work or safe equipment, then during the project execution the client will monitor to ensure that the plan is implemented. This shows that proactively considering H\&S in tender evaluation ensures that the client can manage and monitor the contractor's $H \& S$ implementation in line with the contractor's demonstrated H\&S competence and prescribed solutions in the tender offer.

Hypothesis 4 (H4). The HES provisions made in the conditions of contract will influence contract administration and monitoring.

The relationships suggest that adequate specification of H\&S requirements in the conditions of contract is a predictor of the extent to which the contract will be administered and monitored to ensure that the contractor's H\&S implementation is adequate (significant coefficient 0.49). Contract administration and monitoring is generally aimed at ensuring compliance with contractual provisions throughout the duration of the project. For instance, the conditions of contract may provide for compensation for good H\&S implementation or prescribe damages for doing otherwise. This will require that the H\&S implementations of the contractor be monitored and evaluated by the client or a representative in order to ascertain whether the contractor deserves compensation or a penalty. In such situations, monitoring could be a direct measure to enforcing compliance with the H\&S conditions in the contract.

Hypothesis 5 (H5). Contract administration and monitoring on HES issues will affect the extent of HES implementation on the project.

Figure 3 indicates that adequate monitoring and evaluation of H\&S implementation directly impacts on projects' H\&S implementation (significant coefficient 0.21 ). This relationship is consistent with sociological explanations of law-abidingness, which posits that the regulated entity is motivated to comply with requirements and standards partly due to fear of detection and punishment by the regulator [61]. This means that a significant level of contractual enforcement through sufficient levels of monitoring is essential to generate and ensure compliance, thereby improving implementation. Obviously, the essence of the client's monitoring in respect of H\&S has a reminder effect on the mind of the contractor to work safely throughout the duration of the contract. Monitoring also provides opportunity for the client to proactively act when improper H\&S practices are observed and to ensure that the contractor takes corrective measures. Besides, monitoring and evaluation may be used to determine the level of compensation due the contractor. In this kind of situation where the contractor's safety implementation would be monitored and measured before paying compensation, there is the likelihood that the contractor will act appropriately. Petersen [62] highlighted this in his book entitled Safety by Objective, where he added a caveat: "what gets measured, and rewarded, gets done". This means that if the contractor would be appropriately compensated for H\&S implementation after satisfying the required conditions, such a contractor will likely execute the work safely.

Hypothesis 6 (H6). Clients' general responsibilities and attitudes towards HES will impact on the HES implementation on their projects.

The path analysis shows that the extent to which clients assume their responsibilities towards H\&S has an influence on H\&S implementation on their projects (significant coefficient 0.25 ). This finding has been highlighted by a plethora of studies $[4,6,8]$. Clients have a duty to demonstrate their commitment to H\&S and comply with their responsibilities, such as allocating adequate attention and resources to the implementation of H\&S measures on their projects. Thus, performing this responsibility means that the client does not leave $H \& S$ implementation to the contractors alone but must show interest to set a standard that 
is conducive to a safe working environment. For instance, if a client has a cavalier attitude towards H\&S, then it is likely that everyone involved in the project will develop a similar approach [63]. Although clients may lack H\&S knowledge and experience, yet they can have a positive influence on H\&S implementation by correctly fulfilling their statutory obligations under the applicable H\&S legislation, as a first step towards ensuring a safer construction site.

Hypothesis 7 (H7). Adopting procurement practices because of familiarity or popularity may influence HES implementation on projects.

The initial model hypothesised the above; however, the common procurement practices construct was eliminated from the measurement model during the model evaluation due to poor outer loadings of indicators and inadequate AVE. As a result, its effect on H\&S could not be determined.

\section{Indirect Effects}

The discussions above relate to the direct relationships between the various constructs. However, the path analysis in Figure 3 also shows that indirect relationships exist between some of the constructs. Accordingly, Table 7 has been presented to capture the indirect effects that the constructs have on related ones.

Table 7. Direct and indirect effects of constructs.

\begin{tabular}{|c|c|c|c|c|c|c|}
\hline & & $\begin{array}{l}\text { H\&S in } \\
\text { Tendering }\end{array}$ & $\begin{array}{l}\text { H\&S in Tender } \\
\text { Evaluation }\end{array}$ & $\begin{array}{c}\text { H\&S in Conditions } \\
\text { of Contract }\end{array}$ & $\begin{array}{l}\text { H\&S in Contract Admin. } \\
\text { and Monitoring }\end{array}$ & $\begin{array}{l}\text { H\&S Imple- } \\
\text { mentation }\end{array}$ \\
\hline \multirow{2}{*}{ H\&S Objectives \& planning } & Direct effect & 0.96 & 0.92 & 0.96 & - & - \\
\hline & Indirect effect & - & - & - & 0.85 & 0.18 \\
\hline \multirow{2}{*}{ H\&S in Tendering } & Direct effect & - & - & - & 0.10 & - \\
\hline & Indirect effect & - & - & - & - & 0.02 \\
\hline \multirow{2}{*}{ H\&S in Tender Evaluation } & Direct effect & - & - & - & 0.32 & - \\
\hline & Indirect effect & - & - & - & - & 0.07 \\
\hline \multirow{2}{*}{$\begin{array}{l}\text { H\&S in Conditions } \\
\text { of contract }\end{array}$} & Direct effect & - & - & - & 0.49 & - \\
\hline & Indirect effect & - & - & - & - & 0.10 \\
\hline H\&S in Contract & Direct effect & - & - & - & - & 0.21 \\
\hline Monitoring & Indirect effect & - & - & - & - & - \\
\hline General H\&S & Direct effect & - & - & - & - & 0.25 \\
\hline Responsibilities & Indirect effect & - & - & - & - & - \\
\hline
\end{tabular}

From Table 7, it can be seen that there is a considerable indirect effect of project $H \& S$ objective-setting and planning on contract administration and monitoring (coefficient of 0.85 ). Essentially, this relationship suggests that setting and prioritising project H\&S objectives will eventually cause clients to give more attention to the contractor's H\&S implementation on their projects. It is acknowledged that setting H\&S objectives may directly result in the consideration of $H \& S$ issues in the subsequent stages of procurement including tendering, tender evaluation, and conditions of contracts. Thus, the actions taken in these stages are all processes which are aimed towards achieving the set objectives. For this reason, although the conditions of contract and tender evaluation may establish the conditions upon which the contract administration and monitoring would be carried out, yet the object of the contract administration and monitoring will be the achievement of the set objectives. This is explained by the fact that when clients collect periodic H\&S reports from contractors, these reports are compared against the set objectives or targets.

\section{Conclusions and Further Research}

This study has considered the effect of considering H\&S in the procurement process on the extent of H\&S implementation. The findings from the study demonstrate that clients can promote H\&S on their projects through the procurement process. This starts with the client acknowledging that H\&S is an important issue which needs to be carefully 
considered in setting the project objectives. By integrating H\&S objectives into the overall project objectives, the appropriate consideration is more likely to be given to them when making decisions regarding tendering, tender evaluation, and in preparing the conditions of contracts, reflecting their importance. When the actual construction starts, the decisions made during these stages serve as the basis to monitor the implementation of the H\&S objectives. Adequate and appropriate contract administration and monitoring with respect to $H \& S$ will likely ensure compliance and ultimately result in improved H\&S implementation. The study has also revealed that clients' approach towards their H\&S responsibilities in general is highly correlated with setting $\mathrm{H} \& \mathrm{~S}$ objectives and impacts regarding the H\&S implementation on their projects. However, the effect of adopting common procurement practices on H\&S could not be ascertained.

This study provides a modest framework that can assist clients to integrate H\&S issues into procurement decisions and improve the management of $\mathrm{H} \& \mathrm{~S}$ on their projects. Nonetheless, the model must not be seen as rigid and linear in nature. In practice, based on the client's procurement strategies, the processes and stages may be different or more complicated than those presented in this model. Thus, this research has presented a model that simplifies the complex procurement process which involves the integration of competing objectives and making appropriate decisions in order to promote $\mathrm{H} \& S$ implementation on projects.

This notwithstanding, the model may be applicable to all conventional procurement methods (i.e., traditional, design and build, and management procurement methods). This is because within each of these methods, the process begins with the identification of requirements, which are based on the client's objectives [64]. Subsequently, other key project participants are appointed through the processes of tendering and tender evaluation, and their roles are governed by the conditions of contract. Thus, the procurement method only determines when and how the other project participants would be involved.

This study contributes to the broader academic research on improving H\&S performance in the construction industry by demonstrating that a clear and thoughtful consideration of $H \& S$ issues in the procurement process has a positive impact on project $H \& S$ implementation. The study has the following practical implications; firstly, H\&S legislation in many countries holds clients responsible for the safety of workers on their construction projects and the end users of their facility. Thus, outsourcing the work to a contractor does not take away the client's duty to ensure that those that perform the work are protected from risks. This study has shown that clients can discharge their H\&S obligations on projects and achieve a better $\mathrm{H} \& \mathrm{~S}$ performance by choosing the appropriate procurement strategy. Lastly, monitoring and enforcing $\mathrm{H} \& \mathrm{~S}$ regulations is the responsibility of public regulatory authorities; however, the large number and wide dispersion of construction sites make it practically impossible for H\&S inspectors to regularly inspect all to enforce compliance. This study has established ways by which clients themselves can use the procurement process as a complementary mechanism to enforce compliance with existing H\&S legislations.

Despite the contribution of this study, there are a few limitations worth mentioning. Data were taken from Ghana and therefore the findings may be primarily relevant to Ghana. However, considering that the construction industries in developing countries share similar characteristics [65], the findings may be applicable to other developing countries. The also study relied on a survey of lived experiences of construction industry professionals to determine the causal relationships. While the evidence is enough to draw conclusions, future efforts may focus on collecting actual H\&S performance data, such as site safety data, to determine the actual effect of integrating H\&S in the procurement process.

Author Contributions: E.F.B. is the lead author, completing most of the writing of this paper. R.Y.S. and C.C.W. suggested many revisions that were incorporated in the paper. All authors have read and agreed to the published version of the manuscript.

Funding: This research received no external funding. 
Institutional Review Board Statement: The method used in this study was approved by the Human Research Ethics Committee of UNSW Built Environment (HC190652, Date: 12 September 2019).

Informed Consent Statement: Informed consent was obtained from all participants involved in the study.

Data Availability Statement: Data are available from the authors upon request.

Conflicts of Interest: The authors declare no conflict of interest.

\section{Appendix A}

\section{Survey questionnaire}

Section A: Respondent's details

\begin{tabular}{|c|c|}
\hline Age & $\begin{array}{ll}18-25 & \square \\
46-50 & \square \\
51-55 & \square\end{array}$ \\
\hline 1-2 Years of work experience in the construction industry & $\begin{array}{llll}11-15 \quad \square & 16-20 \quad \square\end{array}$ \\
\hline 1-2 Nature of your organisation & $\begin{array}{l}\text { Consultant } \square \quad \text { Contractor } \square \quad \text { Government organization } \square \\
\text { Supplier } \square \quad \text { Industry/trade association } \square \\
\text { Other (please specify) } \ldots \ldots \ldots \ldots \ldots \ldots \ldots \ldots \ldots \ldots \ldots \ldots \ldots \ldots \ldots \ldots \\
\ldots \ldots \ldots \ldots \ldots\end{array}$ \\
\hline
\end{tabular}

Section B: H\&S issues in public procurement

Objectives \& planning

Please rate how much you agree with each statement about health and safety (H\&S) issues at the planning stages of public sector projects.

\begin{tabular}{|c|c|c|c|c|c|c|}
\hline No & Item & 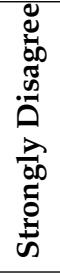 & 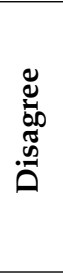 & $\frac{\pi}{\mathbb{\pi}}$ & 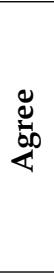 & 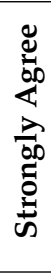 \\
\hline 1 & $\begin{array}{l}\text { Public sector clients usually set health and safety (H\&S) objectives and } \\
\text { targets for their projects. }\end{array}$ & & & & & \\
\hline 2 & $\begin{array}{l}\text { H\&S objectives/targets are as important to public sector clients as other } \\
\text { project objectives such as cost, time and quality. }\end{array}$ & & & & & \\
\hline 3 & $\begin{array}{l}\text { H\&S targets are emphasised and communicated to project team } \\
\text { throughout the procurement stage of public projects. }\end{array}$ & & & & & \\
\hline 4 & $\begin{array}{l}\text { Public clients ensure that their project designers have the capacity and } \\
\text { quality to incorporate safety considerations into designs before } \\
\text { appointing them. }\end{array}$ & & & & & \\
\hline 5 & $\begin{array}{l}\text { H\&S conditions are usually explicitly specified by public clients in the } \\
\text { terms of contract with designers. }\end{array}$ & & & & & \\
\hline 6 & $\begin{array}{l}\text { Public clients develop a client risk register including H\&S risks for their } \\
\text { project. } \\
\text { (N.B. Risk register is a register of all project risks and their mitigation } \\
\text { measures.) }\end{array}$ & & & & & \\
\hline 7 & $\begin{array}{l}\text { When choosing between design options for public projects, H\&S issues } \\
\text { are highly considered. }\end{array}$ & & & & & \\
\hline 8 & $\begin{array}{l}\text { Public clients usually make allocations within their project budgets to } \\
\text { manage H\&S issues. }\end{array}$ & & & & & \\
\hline 9 & $\begin{array}{l}\text { Public clients set the standard for H\&S competence and capacity that a } \\
\text { contractor needs to have in order to work on their projects. }\end{array}$ & & & & & \\
\hline 10 & $\begin{array}{l}\text { Adequate consideration is usually given to H\&S issues when choosing } \\
\text { between the procurement methods for public projects. }\end{array}$ & & & & & \\
\hline
\end{tabular}




\section{Tendering}

Please rate how much you agree with each statement about the tendering practices for public sector projects.

\begin{tabular}{|c|c|c|c|c|c|c|}
\hline No & $\begin{array}{l}\text { Item } \\
\text { H\&S is an important consideration in choosing the tendering methods } \\
\text { to adopt for public projects. }\end{array}$ & 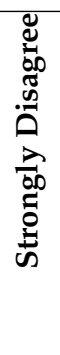 & 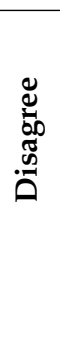 & 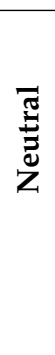 & 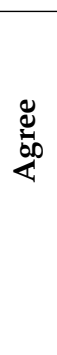 & 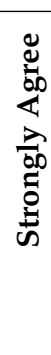 \\
\hline 12 & $\begin{array}{l}\text { Public clients usually specify clearly how H\&S issues must be } \\
\text { addressed in tenders by prospective contractors. }\end{array}$ & & & & & \\
\hline 13 & $\begin{array}{l}\text { Public clients usually include applicable H\&S regulations in their } \\
\text { tender documents to emphasise the requirement for H\&S to be } \\
\text { addressed by contractors. }\end{array}$ & & & & & \\
\hline 14 & $\begin{array}{l}\text { H\&S matters are assigned adequate weight in the tender selection } \\
\text { criteria for public projects. }\end{array}$ & & & & & \\
\hline 15 & $\begin{array}{l}\text { H\&S considerations are among the key criteria used for shortlisting } \\
\text { preferred contractors for public projects. }\end{array}$ & & & & & \\
\hline
\end{tabular}

Tender evaluation and contractor selection

Please rate how much you agree with each statement about tender evaluation and contractor selection for public projects.

\begin{tabular}{|c|c|c|c|c|c|c|}
\hline No & Item & 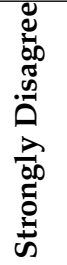 & 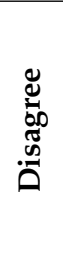 & $\begin{array}{l}\bar{\Xi} \\
\stackrel{\Xi}{\Xi} \\
z\end{array}$ & 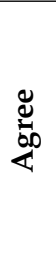 & 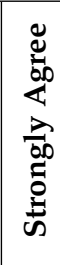 \\
\hline 16 & $\begin{array}{l}\text { Public clients include comprehensive H\&S-related costs in their project } \\
\text { cost estimates in order to compare and evaluate tenderers. }\end{array}$ & & & & & \\
\hline 17 & $\begin{array}{l}\text { H\&S experts are included or consulted in evaluating H\&S aspects of } \\
\text { tenders for public projects. }\end{array}$ & & & & & \\
\hline 18 & $\begin{array}{l}\text { Due diligence (or investigation) is mostly done on each tenderer's H\&S } \\
\text { submissions for public projects. }\end{array}$ & & & & & \\
\hline 19 & $\begin{array}{l}\text { Tenders that do not meet H\&S requirements are not evaluated for } \\
\text { public projects contracts. }\end{array}$ & & & & & \\
\hline 20 & $\begin{array}{l}\text { H\&S submissions can make the difference between a tenderer getting a } \\
\text { contract for a public project or not. (That is, HES competence of tenderers } \\
\text { is one of the key criteria used to select a contractor for public projects). }\end{array}$ & & & & & \\
\hline
\end{tabular}

Conditions of contract

Please rate how much you agree with each statement about the conditions of contract for public sector projects. 


\begin{tabular}{|c|c|c|c|c|c|c|}
\hline No & Item & 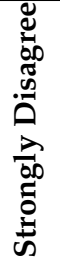 & 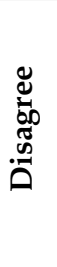 & 苞 & 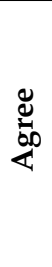 & 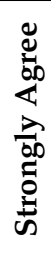 \\
\hline 21 & $\begin{array}{l}\text { H\&S provisions in the standard forms of contracts are mostly adequate } \\
\text { to address the requirements of } H \& S \text { legislations. }\end{array}$ & & & & & \\
\hline 22 & $\begin{array}{l}\text { Public clients usually include additional project-specific conditions of } \\
\text { contract in order to manage project H\&S risks. }\end{array}$ & & & & & \\
\hline 23 & $\begin{array}{l}\text { Contract conditions for public projects prescribe penalty and/or } \\
\text { incentive clauses for poor H\&S performance and accident-free project } \\
\text { delivery respectively. }\end{array}$ & & & & & \\
\hline 24 & $\begin{array}{l}\text { H\&S issues are prominently considered and discussed in contract } \\
\text { negotiations with contractors for public projects. }\end{array}$ & & & & & \\
\hline
\end{tabular}

Contract management/monitoring

Please rate how much you agree with each statement about the H\&S issues in contract management for public sector projects.

\begin{tabular}{|c|c|c|c|c|c|c|}
\hline No & Item & 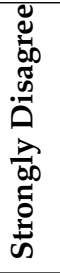 & 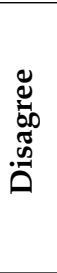 & $\frac{\pi}{\stackrel{\pi}{\pi}}$ & 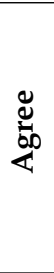 & 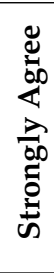 \\
\hline 25 & $\begin{array}{l}\text { Public clients usually collect periodic reports on H\&S during the } \\
\text { construction phase of their projects in order to track H\&S performance. }\end{array}$ & & & & & \\
\hline 26 & $\begin{array}{l}\text { Predetermined H\&S targets are usually used to monitor and track H\&S } \\
\text { performance of contractors on public projects for the entire duration of } \\
\text { the contract. }\end{array}$ & & & & & \\
\hline 27 & $\begin{array}{l}\text { Public clients usually take the necessary actions to improve H\&S } \\
\text { implementation on their project immediately their attention is drawn to } \\
\text { unsafe acts. }\end{array}$ & & & & & \\
\hline 28 & $\begin{array}{l}\text { Public clients always require main contractors on their projects to } \\
\text { nominate subcontractors that are H\&S competent. }\end{array}$ & & & & & \\
\hline
\end{tabular}

General H\&S responsibilities

Please rate how much you agree with each statement about the general H\&S responsibilities of public clients.

\begin{tabular}{|c|c|c|c|c|c|c|}
\hline No & Item & 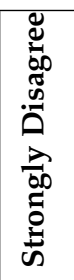 & 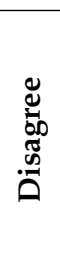 & 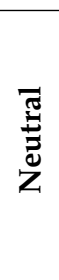 & 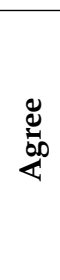 & 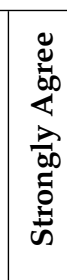 \\
\hline 29 & $\begin{array}{l}\text { Public sector organisations mostly have H\&S policies that guide them } \\
\text { to safely manage their projects. }\end{array}$ & & & & & \\
\hline 30 & $\begin{array}{l}\text { Public clients fully understand their H\&S responsibilities on their } \\
\text { projects. }\end{array}$ & & & & & \\
\hline 31 & $\begin{array}{l}\text { Public clients usually assume full responsibility and control of } \mathrm{H} \& \mathrm{~S} \\
\text { risks on their projects. }\end{array}$ & & & & & \\
\hline 32 & $\begin{array}{l}\text { Contractors' safety costs on public projects are fully reimbursed by } \\
\text { public clients. }\end{array}$ & & & & & \\
\hline 33 & $\begin{array}{l}\text { H\&S performance on public projects is mostly reviewed at the end of } \\
\text { the projects. }\end{array}$ & & & & & \\
\hline
\end{tabular}




\section{Common procurement practices}

Please rate how much you agree with each statement about procurement practices commonly adopted for public projects.

\begin{tabular}{|c|c|c|c|c|c|c|}
\hline No & Item & 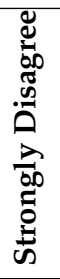 & 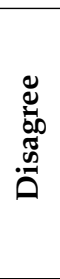 & 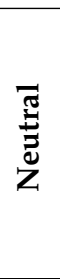 & $\underset{\varpi}{\infty}$ & 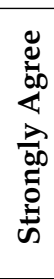 \\
\hline 34 & $\begin{array}{l}\text { Traditional procurement (design-bid-build) method is commonly used } \\
\text { by public clients to deliver their projects. }\end{array}$ & & & & & \\
\hline 35 & $\begin{array}{l}\text { Public clients mostly adopt competitive tendering to select contractors } \\
\text { for their projects. }\end{array}$ & & & & & \\
\hline 36 & $\begin{array}{l}\text { Many public organisations have their preferred list of contractors to be } \\
\text { considered for contract award for their projects. }\end{array}$ & & & & & \\
\hline 37 & $\begin{array}{l}\text { Standard forms of contract (such as FIDIC conditions of contract) are } \\
\text { mostly adopted for public project contracts. }\end{array}$ & & & & & \\
\hline 38 & $\begin{array}{l}\text { Public clients usually designate in-house staff to check on progress of } \\
\text { work and monitor that the contractors are working safely. }\end{array}$ & & & & & \\
\hline
\end{tabular}

H\&S pmplementation

Please rate how much you agree with the statement about H\&S implementation on public sector projects.

\begin{tabular}{|c|c|c|c|c|c|c|}
\hline No & Item & 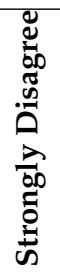 & 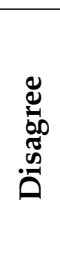 & $\begin{array}{l}\bar{J} \\
\bar{\Xi} \\
z\end{array}$ & 芯 & 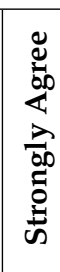 \\
\hline 39 & H\&S implementation on public projects has mostly been very good. & & & & & \\
\hline
\end{tabular}

\section{References}

1. Agumba, J.N.; Haupt, T.C. Construction health and safety culture in South African small and medium enterprises. In Proceedings of the 4th Built Environment Conference, Livingstone, Zambia, 17-19 May 2009; Association of Schools of Construction of Southern Africa: Cape Town, South Africa, 2019; pp. 460-472.

2. Lingard, H.; Blismas, N.; Wakefield, R.; Jellie, D.; Fleming, T. 'Safer construction': The development of a guide to best practice. In Proceedings of the Third International Conference of the Cooperative Research Centre (CRC) for Construction Innovation, Gold Coast, Australia, 12-14 March 2008.

3. Health and Safety Executive. Causal Factors in Construction Accidents; Research Report 156; HMSO Books: Norwich, UK, 2003.

4. Huang, X.; Hinze, J. Owner's role in construction safety. J. Constr. Eng. Manag. 2006, 2, 164-173. [CrossRef]

5. Lingard, H.; Blismas, N.; Cooke, T.; Cooper, H. The model client framework: Resources to help Australian government agencies to promote safe construction. Int. J. Manag. Proj. Bus. 2009, 2, 131-140. [CrossRef]

6. Votano, S.; Sunindijo, R.Y. Client Safety Roles in Small and Medium Construction Projects in Australia. J. Constr. Eng. Manag. 2014, 140, 04014045. [CrossRef]

7. Health and Safety Commission. Managing health and safety in construction. In Construction (Design and Management) Regulations 2007l; Health and Safety Commission: Norwichm, UK, 2007.

8. Wild, B. Occupational Health and Safety-The Caring Client. In Clients Driving Construction Innovation: Mapping the Terrain; Brown, K., Hampson, K., Brandon, P., Eds.; CRC for Construction Innovation: Brisbane, Australia, 2005; pp. 22-39.

9. Lingard, H.; Oswald, D.; Le, T. Embedding occupational health and safety in the procurement and management of infrastructure projects: Institutional logics at play in the context of new public management. Constr. Manag. Econ. 2019, 37, 567-583. [CrossRef]

10. Umeokafor, N.; Windapo, A.; Olatunji, O. Integrating health and safety into labour-only procurement system: Opportunities, barriers and strategies. In Construction Health and Safety in Developing Countries; Manu, P., Emuze, F., Saurin, T., Hadikusumo, B.H.W., Eds.; Abingdon: Routledge, UK, 2020; pp. 140-151.

11. Office of the Federal Safety Commissioner. The Model Client Framework: The Model Client: Promoting Safe Construction; Office of the Federal Safety Commissioner: Canberra, Australia, 2008. 
12. Worksafe Victoria. A Handbook for the Public Sector. Health and Safety in Construction Procurement, 2nd ed.; Worksafe Victoria: Geelong, Australia, 2017.

13. Wells, J.; Hawkins, J. Briefing: Promoting construction health and safety through procurement. Proc. Inst. Civil Eng. Manag. Procure. Law 2011, 164, 165-168.

14. Boadu, E.F.; Sunindijo, R.Y.; Wang, C.C. Health and safety consideration in the procurement of public construction projects in Ghana. Buildings 2021, 11, 128. [CrossRef]

15. Health and Safety Executive. Health and Safety in Public Sector Construction Procurement; Health and Safety Executive: London, UK, 2007.

16. Health and Safety Executive. Health and Safety in Public Sector Construction Procurement, A Follow-Up Study; Health and Safety Executive: London, UK, 2011.

17. Benviolent, C.; Smallwood, J. Assessing the implications of public sector procurement on construction health and safety management in Zimbabwe. In Proceedings of the 9th CIDB Conference. Emerging Trends in Construction Organisational Practices and Project Management Knowledge Areas, Cape Town, South Africa, 2-4 February 2016; Windapo, A.O., Odediran, S.J., Adediran, A., Eds.; University of Cape Town: Cape Town, South Africa, 2016.

18. Akintoye, A.; Main, J. Innovation through Collaborative Procurement Strategy and Practices. In Construction Innovation and Process Improvement; Akintoye, A., Goulding, J.S., Zawdie, G., Eds.; John Wiley and Sons: Hoboken, NJ, USA, 2012.

19. International Organization for Standardization (ISO). ISO 10845-1:2010: Construction Procurement-Part 1: Processes, Methods and Procedures; ISO: Geneva, Switzerland, 2010.

20. Watermeyer, R. The critical role of consulting firms in the acceleration of infrastructure delivery and the improvement of the quality of life. In New Perspectives on Construction in Developing Countries; Ofori, G., Ed.; Spon Press: London, UK, 2012.

21. Miller, G.; Furneaux, C.; Davis, P.; Love, P.; O’Donnell, A. Built Environment Procurement Practice: Impediments to Innovation and Opportunities for Changes; Curtin University of Technology: Perth, Australia, 2009.

22. Sanderson, J.; Lonsdale, C.; Mannion, R.; Matharu, T. Towards a framework for enhancing procurement and supply chain management practice in the NHS: Lessons for managers and clinicians from a synthesis of the theoretical and empirical literature. Health Serv. Deliv. Res. 2015, 3. [CrossRef]

23. Construction Industry Development Board (CIDB). Delivery Management Guidelines: Practice Guide 2-Construction Procurement Strategy; CIDB: Pretoria, South Africa, 2011.

24. Mortledge, R.; Smith, A.; Kashiwagi, D.T. Building Procurement; Blackwell: Oxford, UK, 2006.

25. Anderson, N.H. Foundations of Information Integration Theory; Academic Press: Boston, MA, USA, 1981; ISBN 0-12-058101-9.

26. Koehn, E.; Datta, N. Quality, Environmental, and Health and Safety Management Systems for Construction Engineering. J. Constr. Eng. Manag. 2003, 129, 562-569. [CrossRef]

27. Worksafe Victoria. Handbook for the Public Sector. Health and Safety in Construction Procurement, 1st ed.; Worksafe Victoria: Geelong, Australia, 2010.

28. Frey, C.J.; Kinnear, T.C. Information Integration Theory: An Alternative Attitude Model for Consumer Behaviour. Adv. Consum. Res. 1980, 7, 350-355.

29. Constructing Excellence. Procurement. Available online: http://constructingexcellence.org.uk/wp-content/uploads/2015/03/ procurement.pdf (accessed on 5 May 2019).

30. Csaki, C. Investigating the decision-making practice of public procurement procedures. In Proceedings of the International Public Procurement Conference, Rome, Italy, 21-23 September 2006.

31. Render, B.; Stair, R.M.; Hanna, M.E.; Hale, T.S. Quantitative Analysis for Management, 13th ed.; Pearson: Harlow, UK, 2018.

32. Cheaitou, A.; Larbi, R.; Housani, B.A. Decision making framework for tender evaluation and contractor selection in public organizations with risk considerations. Socio Econ. Plan. Sci. 2018, 68, 100620. [CrossRef]

33. Hatush, Z.; Skitmore, M. Contractor selection using multicriteria utility theory: An additive model. Build. Environ. 1998, 33, 105-115. [CrossRef]

34. Harrison, F.E. The Managerial Decision-Making Process, 4th ed.; Houghton Mifflin Company: Boston, MA, USA, 1995.

35. Eisenhardt, K.M.; Zbaracki, M.J. Strategic Decision Making. Strateg. Manag. J. 1992, 13, 17-37. [CrossRef]

36. Creswell, J.W. Research Design: Qualitative, Quantitative and Mixed Methods Approaches, 4th ed.; Sage: Thousand Oaks, CA, USA, 2014.

37. Chin, W.W.; Marcolin, B.L.; Newsted, P.R. A Partial Least Squares Latent Variable Modeling Approach for Measuring Interaction Effects: Results from a Monte Carlo Simulation Study and an Electronic-Mail Emotion/Adoption Study. Inf. Syst. Res. 2003, 14, 189-217. [CrossRef]

38. Daniel, W.W. Biostatistics: A Foundation for Analysis in the Health Sciences, 7th ed.; John Wiley \& Sons: New York, NY, USA, 1999.

39. Root, D.; Blismas, N.G. Increasing questionnaire responses from industry: Practices surrounding the use of postal questionnaires. In Proceedings of the 19th Annual ARCOM Conference, Brighton, UK, 3-5 September 2003; Greenwood, D.J., Ed.; Association of Researchers in Construction Management: Reading, UK, 2003; Volume 2, pp. 623-631.

40. Schreiber, J.B.; Stage, K.F.; King, J. Reporting structural equation modelling and confirmatory factor analysis results: A review. J. Educ. Res. 2006, 99, 323-337. [CrossRef]

41. Henseler, J.; Ringle, C.M.; Sinkovics, R.R. The use of partial least squares path modelling in international marketing. Adv. Int. Mark. 2009, 20, 277-319.

42. Byrne, B.M. Structural Equation Modeling with AMOS: Basic Concepts, Applications, and Programming, 3rd ed.; Routledge: New York, NY, USA, 2016. 
43. Kline, B.R. Principles and Practice of Structural Equation Modelling, 2nd ed.; The Guilford Press: New York, NY, USA, 2005.

44. Hair, J.F., Jr.; Black, W.C.; Babin, B.J.; Andersen, R.E. Mutilvariate Data Analysis, 7th ed.; Pearson Prentice Hall: Upper Saddle River, NJ, USA, 2010.

45. Ramayah, T.; Lee, J.W.C.; In, J.B.C. Network collaboration and performance in the tourism sector. Serv. Bus. 2011, 5, 411-428. [CrossRef]

46. Hair, J.F., Jr.; Matthews, L.M.; Matthews, R.L.; Sarstedt, M. PLS-SEM or CB-SEM: Updated guidelines on which method to use. Int. J. Multivar. Data Anal. 2017, 1, 107-123. [CrossRef]

47. Kline, R.B. Principles and Practice of Structural Equation Modelling; Guilford Press: New York, NY, USA, 2011.

48. Pallant, Y. SPSS Survival Manual: A Step by Step Guide to Data Analysis Using SPSS for Windows, 3rd ed.; McGraw Hill Open University Press: Berkshire, UK, 2001.

49. Henseler, J.; Sarstedt, M. Goodness-of-fit indices for partial least squares path modelling. Compu. Stat. 2013, 28, 565-580. [CrossRef]

50. Hair, J.F.; Hult, G.T.M.; Ringle, C.M.; Sarstedt, M. A Primer on Partial Least Squares Structural Equation Modeling (PLS-SEM); Sage: Thousand Oaks, CA, USA, 2014.

51. Carmines, E.G.; Zeller, R.A. Reliability and Validity Assessment; Sage: Thousand Oaks, CA, USA, 1979.

52. Chin, W.W. The partial least squares approach to structural equation modelling. In Modern Methods for Business Research; Marcoulides, G.A., Ed.; Lawrence Erlbaum: Mahwah, NJ, USA, 1998; pp. 295-358.

53. Lohmöller, J.-B. Latent Variable Path Modeling with Partial Least Squares; Physica: Heidelberg, Germany, 1989.

54. Henseler, J.; Ringle, C.M.; Sarstedt, M. A new criterion for assessing discriminant validity in variance-based structural equation modelling. J. Acad. Mark. Sci. 2015, 43, 115-135. [CrossRef]

55. Kenny, D.A.; Kaniskan, B.; McCoach, D.B. The performance of RMSEA in models with small degrees of freedom. Sociol. Methods Res. 2015, 44, 486-507. [CrossRef]

56. Watt, D.J.; Kayis, B.; Willey, K. The relative importance of tender evaluation and contractor selection criteria. Int. J. Proj. Manag. 2010, 28, 51-60. [CrossRef]

57. Lingard, H.; Rowlinson, S. Occupational Health and Safety in Construction Project Management; Spon Press: Oxon, UK, 2005.

58. Enyinda, C.; Ogbuehi, A.; Udo, G. A Decision Support Model for Contractor Selection in a Government Procurement Supply Chain: Evidence from an Emerging Market. J. Manag. Policy Pract. 2011, 12, 9-17.

59. Government of Victoria. Social Procurement-Evaluating Social and Sustainable Procurement Objectives and Outcomes. 2019. Available online: https:/ / www.buyingfor.vic.gov.au/social-procurement-evaluating-social-and-sustainable-procurementobjectives-and-outcomes (accessed on 6 October 2020).

60. Sharkey, J.A.M.; Bell, M.; Jocic, W.; Marginean, R. Standard Forms of Contract in the Australian Construction Industry: Research Report. 2014. Available online: https:/ / law.unimelb.edu.au/_data/assets/pdf_file/0007/1686265/Research-Report-Standardforms-of-contract-in-the-Australian-construction-industry.pdf (accessed on 11 September 2020).

61. Gunningham, N. Compliance, Enforcement, and Regulatory Excellence; Penn Program on Regulation; University of Pennsylvania: Philadelphia, PA, USA, 2015.

62. Petersen, D. Safety by Objectives: What Gets Measured and Rewarded Gets Done, 2nd ed.; Van Nostrand Reinhold: New York, NY, USA, 1996.

63. Perry, P. CDM Questions and Answers, A Practical Approach; Thomas Telford: London, UK, 1999.

64. McCue, C.; Gianakis, G. Public purchasing: Who's minding the store? J. Public Procure. 2001, 1, 71-95. [CrossRef]

65. Boadu, E.F.; Wang, C.C.; Sunindijo, R.Y. Characteristics of the construction industry in developing countries and its implications for health and safety: An exploratory study in Ghana. Int. J. Environ. Res. Public Health 2020, 17, 4110. [CrossRef] 